\title{
SCIENTIFIC REPORTS

\section{OPEN Characterization and assessment of barnacle larval settlement-inducing activity of extracellular polymeric substances isolated from marine biofilm bacteria}

\begin{abstract}
Aboobucker Siddik (1) \& Sathianeson Satheesh (i)
Extracellular polymeric substances (EPSs) are the hydrated gelatinous matrix produced by microorganisms for attachment in a biofilm environment. In this study, the compositional variation between EPSs of three marine biofilm bacteria (Pseudoalteromonas shioyasakiensis, Vibrio harveyi and Planomicrobium sp.) were analysed by GC-MS, ${ }^{1} \mathrm{H}$ NMR, FT-IR and XRD and SEM. The ecological significance of exopolymers was assessed in vivo using marine model organism barnacle larvae for their settlement-inducing activity. Chemical analysis revealed the presence of glycan fucosylated oligosaccharides, tetraose, trisaccharides, iso-B-Pentasaccharides, sialyllactose, oligomannose, galacto- $N$-biose, difucosyl-para-lacto- $N$-neohexaose, $3^{\prime}$-sialyl $N$-acetyllactosamine and isoglobotriaose- $\beta$ - $N$ (Acetyl)-Propargyl in all extracted EPSs. Bioassay results indicated that treatment of the barnacle larvae with EPSs from three bacterial strains enhanced settlement on substrates. In conclusion, this study highlighted the role of water-soluble EPSs in the invertebrate larval settlement on artificial materials.
\end{abstract}

Persistence of marine benthic population has been determined by the larval settlement and metamorphosis of marine invertebrates ${ }^{1}$. Marine invertebrates begin settlement by responding to biological or chemical stimuli or cues $^{2}$. Biological and chemical cues such as microbial biofilm, conspecific cues, extracellular polymers, free fatty acids, peptides, crustose coralline algae, neurotransmitter compounds, quorum sensing compounds and tetrabromopyrrole have been reported to induce settlement of larval forms of marine organisms ${ }^{3-11}$. Among the cues, extracellular polymeric substances (EPSs) or exopolymers are the gelatinous matrix produced by microorganisms for their linkage or attachment in a biofilm environment ${ }^{12}$. High molecular weight polysaccharides are the major constituents of exopolymers produced by microorganisms ${ }^{13,14}$. The other components of EPSs include proteins, amyloid fibrils, nucleic acids and uronic acids ${ }^{12,15,16}$.

The composition and structure of exopolymers vary between bacterial species, and is highly dependent on the nutrient source and environmental conditions ${ }^{13,17}$. The detailed analysis and characterization of exopolymers is difficult. Least explained in the literature is the composition of polymeric substances and their role in larval settlement and metamorphosis ${ }^{18,19}$. The majority of exopolymers derived from marine microbes are natural heteropolysaccharides, composed of different repeat monomers ${ }^{20}$. The characterization of exopolymers produced by marine biofilm bacteria is important for understanding the interaction between larvae and biofilms ${ }^{21}$.

Experimental evidence has substantially proved that exopolymers from different microbial origin have different effects (induction or inhibition) against marine invertebrate larvae ${ }^{10,22,23}$. For instance, Morse and Morse ${ }^{24}$ reported that the sulphated polysaccharides present in algal cell surfaces induced the settlement of coral Agaricia humilis larvae. Also, the high molecular weight extracellular polymers of diatom species Achnanthes sp. and Nitzschia constricta induced the larval settlement of Hydroides elegans, whereas the low molecular weight exopolymers induced a low number of larval settlement ${ }^{5}$. Inversely, extracellular polymers derived from the marine biofilm bacteria Roseobacter litoralis have no settlement-inducing effect on H. elegans ${ }^{25}$. The exopolymers of biofilms, 

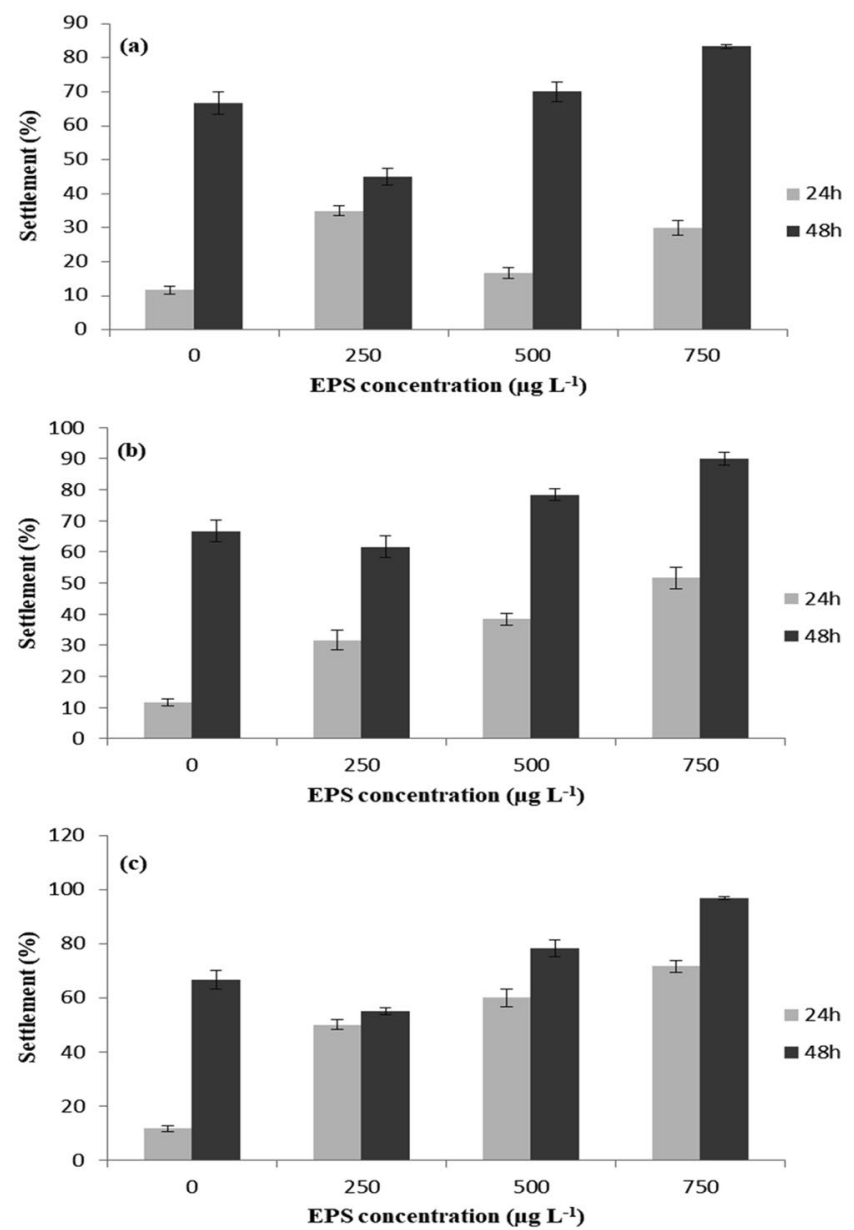

Figure 1. Barnacle larval settlement (mean $\pm S D, n=6$ ) in response to different concentrations of EPS isolated from (a) Pseudoalteromonas shioyasakiensis EPS-Psh, (b) Vibrio harveyi EPS-Vha and (c) Planomicrobium sp. EPS-Pla.

\begin{tabular}{|l|l|l|l|l|l|l|l|}
\hline \multirow{2}{*}{ Source of Variation } & \multicolumn{3}{l}{ EPS-Psh } & EPS-Vha & \multicolumn{3}{l|}{ EPS-Pla } \\
\cline { 2 - 9 } & df & F & P & F & P & F & P \\
\hline Time & 1 & 48.6205 & 0.000 & 27.377 & 0.000 & 14.784 & 0.0004 \\
\hline Concentration & 3 & 1.739 & 0.174 & 3.15 & 0.0352 & 8.507 & 0.0001 \\
\hline Interaction & 3 & 3.182 & 0.034 & 0.444 & 0.722 & 2.476 & 0.0751 \\
\hline Within & 40 & & & & & & \\
\hline Total & 47 & & & & & &
\end{tabular}

Table 1. Two-way ANOVA results for the cyprid settlement treated with different concentrations of EPS. ${ }^{*} P<0.05=$ significant.

diatom species and Pseudomonas aeruginosa induced settlement and metamorphosis in Amphibalanus amphitrite larvae ${ }^{26,27}$. Conversely, exopolymers derived from Bacillus pumilus and Citrobacter freundii showed no effect on settlement and metamorphosis of $A$. amphitrite larvae ${ }^{27}$.

In this study, an attempt was made to assess the settlement-inducing activity of EPSs produced by marine biofilm-forming bacteria isolated from artificial materials submerged in the central Red Sea. Exopolymers isolated from biofilm bacterial strains were tested against the larvae of barnacle A. amphitrite. Like other marine invertebrates, $A$. amphitrite has greater ecological significance among rocky intertidal habitats and it is also commonly used as a model organism in antifouling studies ${ }^{28-30}$. Specifically, the following questions were addressed in this study: (1) do the exopolymers induce settlement and metamorphosis of A. amphitrite larvae? and (2) is the chemical composition similar in all the three exopolymers isolated from P. shioyasakiensis, $V$. harveyi and Planomicrobium sp.? Results obtained in this study will further advance our knowledge of the role of marine biofilms in larval settlement. 

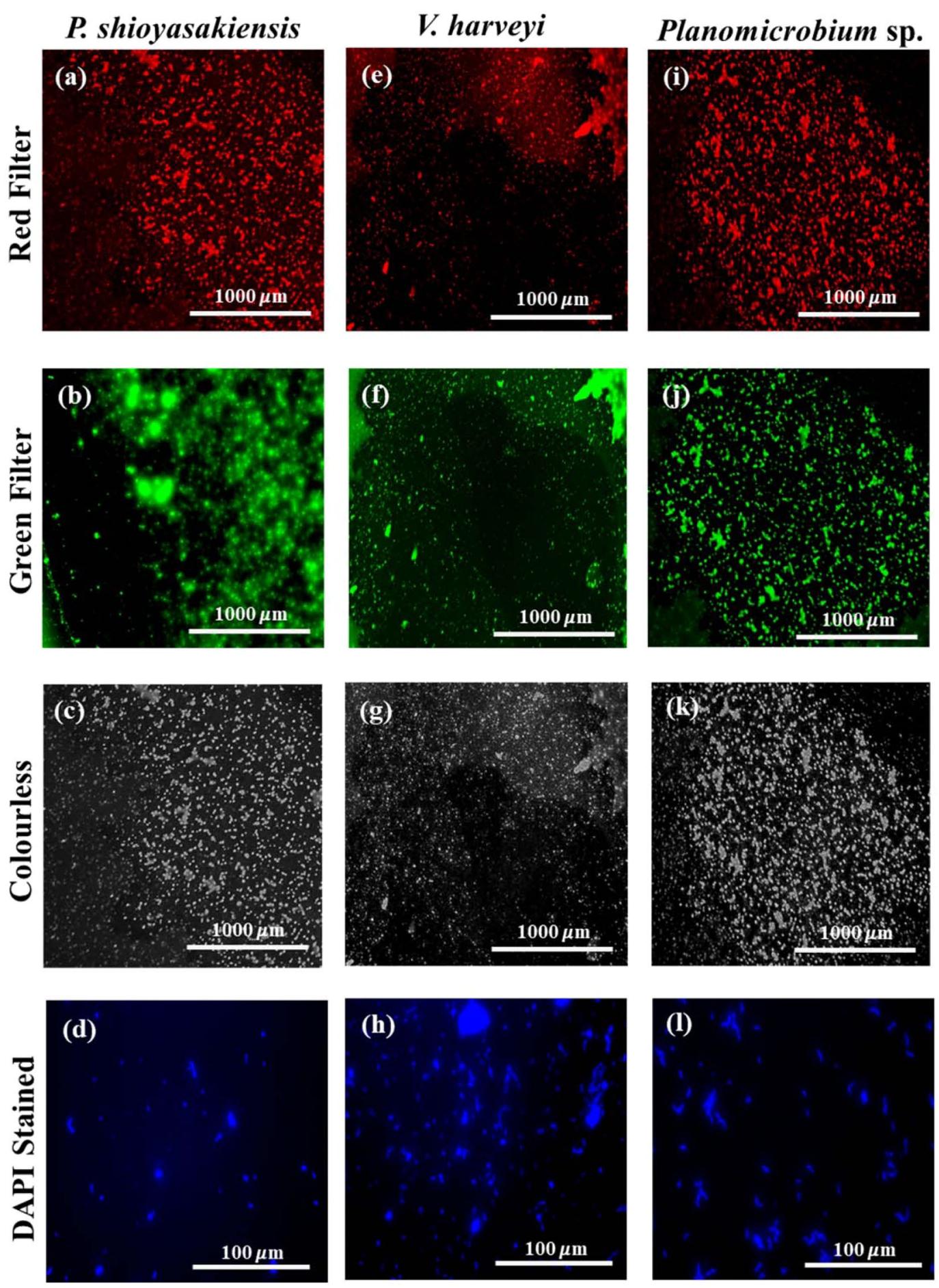

Figure 2. Fluorescence microscopy visualization of biofilms developed on 24-well cell culture plates (a-c) Pseudoalteromonas shioyasakiensis, (e-g) Vibrio harveyi and (i-k) Planomicrobium sp. DAPI staining of biofilm bacterial cells (scale $100 \mu \mathrm{m}$ ): (d) P. shioyasakiensis, (h) V. harveyi and (1) Planomicrobium sp.

\section{Results \\ Larval toxicity and settlement assay. Exopolymers obtained from P. shioyasakiensis, V. harveyi and Planomicrobium sp. showed no toxicity towards barnacle nauplii after 24 and $48 \mathrm{~h}$. Mortality was not observed during the treatment. Further, EPSs enhanced the settlement of barnacle larvae. The larval settlement of $A$. amphitrite increased considerably with increasing concentrations of EPSs (Fig. 1a-c). In the control group, $11.66 \%$ of cyprid settlement was observed after $24 \mathrm{~h}$. After $48 \mathrm{~h}, 66.66 \%$ of cyprid settlement was noticed in the control group. Moreover, the maximum percentage of settlement (96.66\%) was observed in cyprids treated with $750 \mathrm{\mu gl}^{-1}$ concentrations of EPS-Pla. The larval groups treated with EPS-Psh and EPS-Vha showed a maximum cyprid settlement of $83.33 \%$ and $90 \%\left(750 \mu^{-1} \mathrm{l}^{-1}\right)$ respectively. The $\mathrm{EC}_{50}$ values of EPS-Psh, EPS-Vha and EPS-Pla}



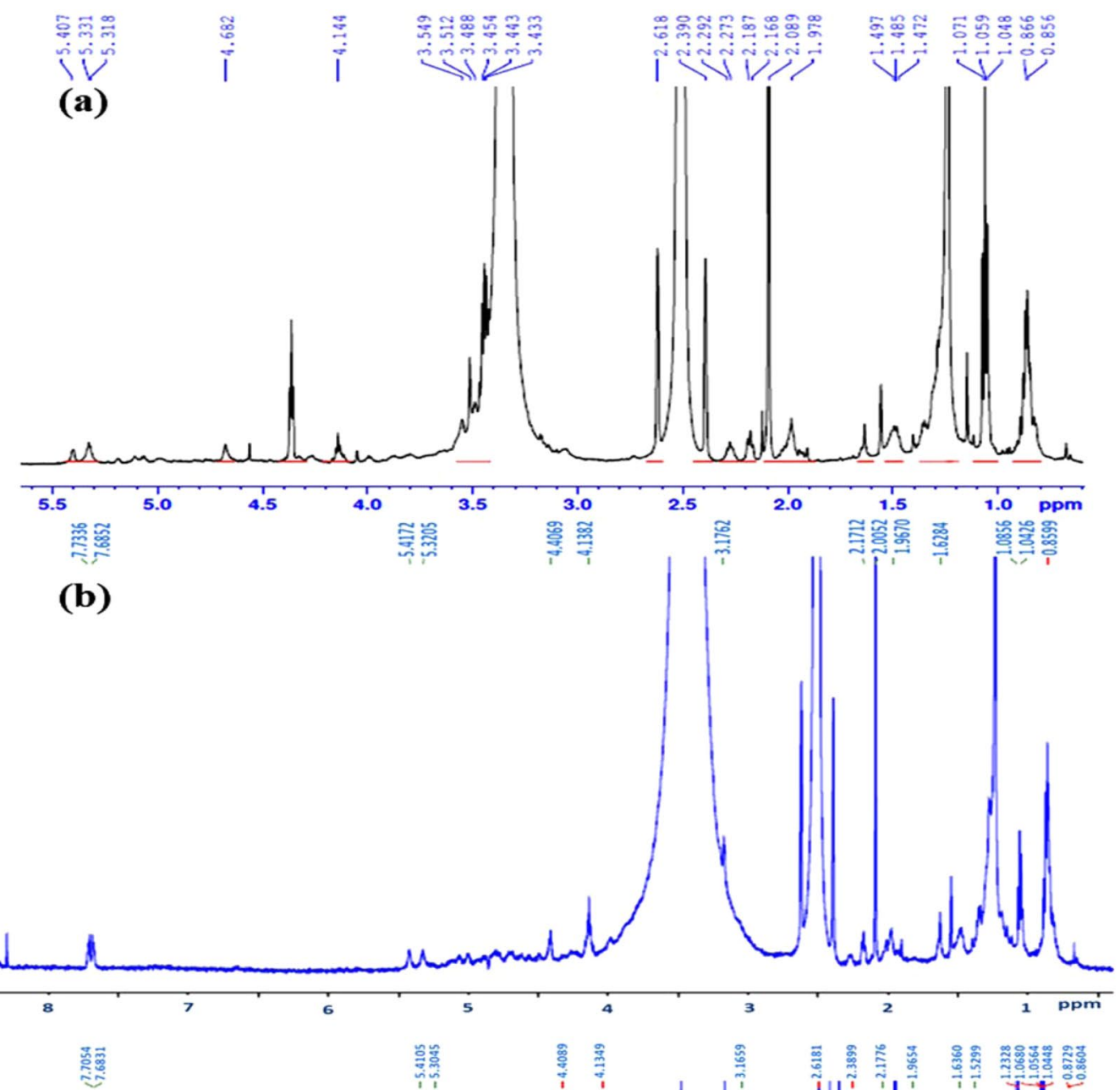

(c)

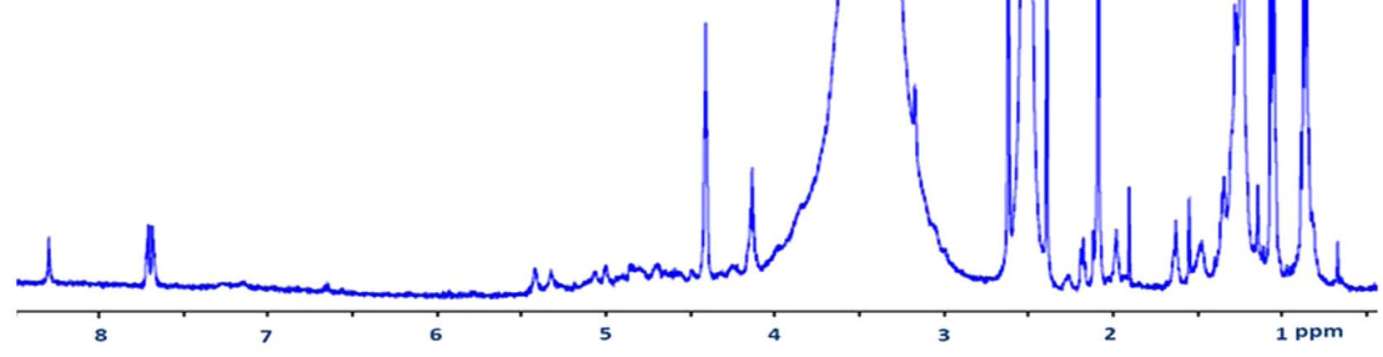

Figure 3. Proton $\left({ }^{1} \mathrm{H}\right)$ NMR spectroscopy analysis of EPS isolated from (a) Pseudoalteromonas shioyasakiensis, (b) Vibrio harveyi and (c) Planomicrobium sp.

\begin{tabular}{|c|c|c|}
\hline EPS & $\begin{array}{l}\text { Total carbohydrate content } \\
\left(\mu \mathrm{g} \mathrm{mg}^{-1}\right)\end{array}$ & $\begin{array}{l}\text { Total protein } \\
\text { content }\left(\mu \mathrm{g} \mathrm{mg}^{-1}\right)\end{array}$ \\
\hline EPS-Psh & 130 & 45 \\
\hline EPS-Vha & 88 & 38 \\
\hline EPS-Pla & 111 & 64 \\
\hline
\end{tabular}

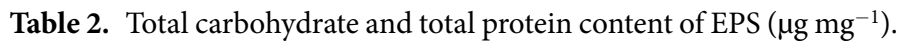

were $498.29,494.36$ and $500.09 \mu \mathrm{gl} 1^{-1}$ respectively. Two-way analysis of variance (ANOVA) revealed a significant variation in the settlement of larvae treated with different concentrations of EPS-Vha and EPS-Pla (Table 1). The settlement of larvae treated with different concentrations of EPS-Psh did not show significant difference between 

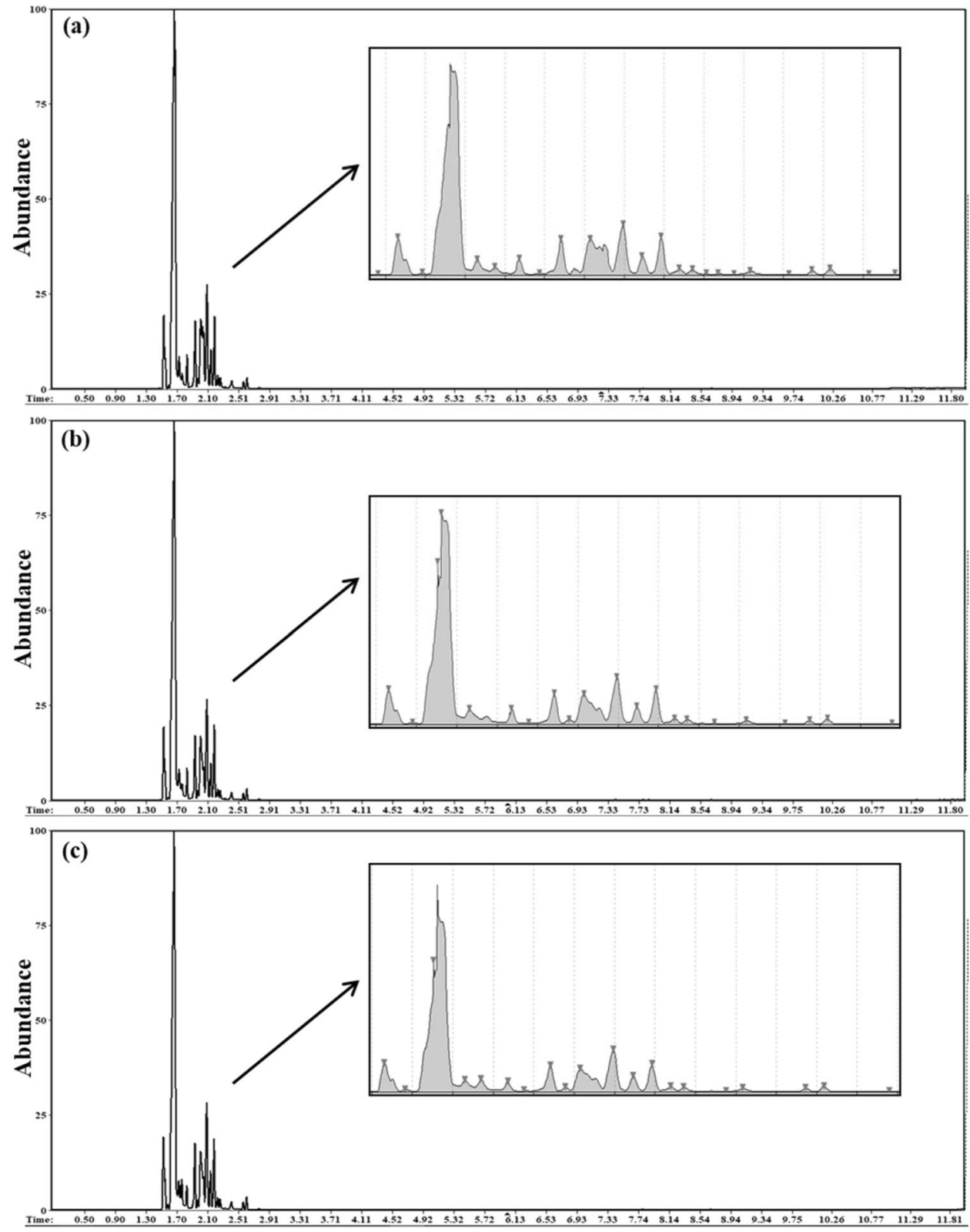

Figure 4. GC-MS analysis of EPS isolated from (a) Pseudoalteromonas shioyasakiensis, (b) Vibrio harveyi and (c) Planomicrobium sp.

treatments. However, the interaction between concentration and observation time revealed significant variation (Table 1).

Fluorescence microscopy imaging of biofilm. Microscopy images confirmed the biofilm-forming ability of the three bacterial strains under laboratory conditions. The direct fluorescence microscopy imaging of 24-h-grown biofilms is shown in Fig. 2. The biofilm images were captured using different filters: red filter (Fig. 2a-c), green filter (Fig. 2e-g), colourless (visible) filter (Fig. 2i-k) and DAPI filter (Fig. 2d,h,l). The biofilm mats formed by bacterial cells were visible at the scale of $1000 \mu \mathrm{m}$ ( $4 \mathrm{x}$ objective). An enlarged view of biofilm bacterial cells captured using $40 \mathrm{x}$ objective $(100 \mu \mathrm{m}$ scale) is presented in Supplementary Fig. 2. DAPI stain clearly showed the presence of bacterial cells in biofilm matrix.

${ }^{1} \mathrm{H}$ NMR analysis. The $600 \mathrm{MHz}$ proton NMR spectra of EPSs in DMSO are shown in Fig. 3a,b,c. The ${ }^{1} \mathrm{H}$ NMR spectral peaks of EPS-Psh were observed at $\delta 0.85,0.86,1.04-1.07 \mathrm{ppm}$, alkyl region 1.47-1.49 ppm, 2.08$2.61 \mathrm{ppm}$, ring proton region $3.43-3.54,4.14 \mathrm{ppm}$, anomeric proton region 4.68 and $5.31-5.40 \mathrm{ppm}$. EPS-Vha and EPS-Pla have mass shift at $\delta 0.86 \mathrm{ppm}, 1.04-1.08 \mathrm{ppm}$, alkyl region 2.08-2.17 ppm, anomeric proton region 4.13-4.40 ppm, 5.30-5.41 ppm and 7.68-7.70 ppm. The spectral peaks of EPS-Vha and EPS-Pla were similar to each other. 


\begin{tabular}{|l|l|l|l|l|}
\hline & Glycosyl composition & Target Ion $[\mathrm{m} / \mathrm{z}]$ & Retention Time & Intensity \\
\hline 1 & Glycan Le-b Tetraose & 99 & 1.48 & 2912731 \\
\hline 2 & Difucosyl-para-lacto- $N$-neohexaose & 74 & 1.53 & $1.90 \mathrm{E}+08$ \\
\hline 3 & 6'-Sialyllactose & 71 & 1.59 & 8506785 \\
\hline 4 & Sialyl-Lacto- $N$-tetraose & 73 & 1.73 & $7.82 \mathrm{E}+07$ \\
\hline 5 & A-Trisaccharide & 70 & 1.78 & $3.97 \mathrm{E}+07$ \\
\hline 6 & 6'-Sialyllactose & 71 & 1.84 & $7.96 \mathrm{E}+07$ \\
\hline 7 & N-acetyllactosamine & 87 & 1.89 & 5159836 \\
\hline 8 & 3'-Sialyl Lewis X & 83 & 1.94 & $1.82 \mathrm{E}+08$ \\
\hline 9 & Glycan fucosylated oligosaccharide & 79 & 2.01 & $1.82 \mathrm{E}+08$ \\
\hline 10 & H-Trisaccharide & 74 & 2.1 & $2.54 \mathrm{E}+08$ \\
\hline 11 & iso-B-Pentasaccharide & 97 & 2.14 & $9.45 \mathrm{E}+07$ \\
\hline 12 & Galacto- $N$-biose & 84 & 2.19 & $1.93 \mathrm{E}+08$ \\
\hline 13 & iso-B-Pentasaccharide & 97 & 2.24 & $2.98 \mathrm{E}+07$ \\
\hline 14 & Sialylated tetrose type 2 & 97 & 2.27 & $2.57 \mathrm{E}+07$ \\
\hline 15 & Unidentified & 85 & 2.31 & 4837636 \\
\hline 16 & Isoglobotriaose- $\beta$ - $N$ (Acetyl)-Propargyl & 71 & 2.34 & 5358300 \\
\hline 17 & Oligomannose 8 D1D3 & 99 & 2.38 & 3234973 \\
\hline 18 & Glycan fucosylated oligosaccharide & 83 & 2.42 & $2.03 \mathrm{E}+07$ \\
\hline 19 & A-Type II Tetrasaccharide & 95 & 2.51 & 3143567 \\
\hline 20 & Unknown compounds & 91 & 2.57 & $2.18 \mathrm{E}+07$ \\
\hline 21 & Unknown compounds & 91 & 2.62 & $3.10 \mathrm{E}+07$ \\
\hline 22 & 3'-Sialyl Lewis X & 82 & 2.72 & 1554738 \\
\hline 23 & Unidentified & 91 & 2.78 & 4485566 \\
\hline 24 & A-Type II Tetrasaccharide & 111 & 3.86 & 1236336 \\
\hline 25 & Oligomannose 8 A & 161 & 7.79 & 3071352 \\
\hline 26 & Oligomannose 3 A & 206 & 7.87 & 2074843 \\
\hline 27 & Oligomannose 5 & 8.06 & 2075195 \\
\hline 28 & Galacto- $N$-biose & 8.69 & 4617695 \\
\hline & & 207 & \\
\hline & & & \\
\hline
\end{tabular}

Table 3. GC-MS analysis of glycosyl composition of exopolymers isolated from Pseudoalteromonas shioyasakiensis (EPS-Psh).

GC-MS analysis. The total carbohydrate and protein content of the EPSs are shown in Table 2. Glycosyl composition analysis of EPSs produced by P. shioyasakiensis, V. harveyi and Planomicrobium sp. (Fig. 4a,b,c) showed that the EPS consists of tetraose, trisaccharides, iso-B-Pentasaccharides, sialyllactose, oligomannose, galacto- $N$-biose, glycan fucosylated oligosaccharide, $3^{\prime}$-sialyl Lewis $\mathrm{X}$, difucosyl-para-lacto- $N$-neohexaose, $3^{\prime}$-sialyl $N$-acetyllactosamine and isoglobotriaose- $\beta-N$ (Acetyl)-Propargyl (Tables 3-5). The variations in glycosyl composition among three EPSs (EPS-Psh, EPS-Vha and EPS-Pla) were determined using principal component analysis (PCA), a non-targeted multivariate statistical tool. The PCA scree plot of the accumulated variance explained by PC1-PC7 showed that PC1 contributed $48.4 \%$ to the total variance observed (Fig. 5a). The other significant components are given by PC2-PC7 with percentage contributions of $19.3 \%, 13.9 \%, 10.6 \%, 3.3 \%, 2.5 \%$ and $1.6 \%$ respectively. PC1-PC7 accounted for $99.7 \%$ of the accumulated variance of the samples. The PCA score plot and biplot of the principal components PC1 and PC2 showed that exopolymers of EPS-Psh, EPS-Vha and EPS-Pla were categorized in the same cluster except VHA2 and PSH3 (Fig. 5a,b). The correlation heatmap analysis showed that Glycan Le-b tetraose and iso-B-Pentasaccharides are closely related to each other (Fig. 5c).

FT-IR analysis. The FT-IR spectra of exopolymers EPS-Psh, EPS-Vha, and EPS-Pla are shown in Fig. 6. The IR spectra of all the three exopolymers were similar and displayed a broad stretching peak at $3407-3414 \mathrm{~cm}^{-1}$ possibly due to the presence of a hydroxyl group. Peaks were also observed around $2926-2929 \mathrm{~cm}^{-1}, 1637-1646$ $\mathrm{cm}^{-1}, 1421-1424 \mathrm{~cm}^{-1}, 1127-1147 \mathrm{~cm}^{-1}$ and 500-650 $\mathrm{cm}^{-1}$. A small peak was observed around $2356 \mathrm{~cm}^{-1}$ in EPS-Psh, but not in EPS-Vha and EPS-Pla.

X-ray diffraction analysis of EPS. The XRD spectra (Fig. 7a-c) of three EPSs with their respective inter-planar spacings (d-spacings) indicate the crystalline nature of exopolymers (Fig. 7). The XRD spectral patterns of EPS are attributed to amorphous characteristics, with a crystalline phase. The crystalline index $\left(\mathrm{CI}_{\mathrm{XRD}}\right)$ of extracted EPSs was calculated for determining the crystalline and amorphous phases and the values are shown in Table 6.

SEM analysis of EPS. The SEM images of three EPSs clearly described the compact nature of exopolymers (Fig. 8). There was no visible difference in the morphology of all the three EPSs. The exopolymers obtained from P. shioyasakiensis, V. harveyi and Planomicrobium sp. consisted of aggregated and irregular sphere-shaped particles under $5.0 \mathrm{kx}$ magnification. 


\begin{tabular}{|c|c|c|c|c|}
\hline & Glycosyl composition & $\begin{array}{l}\text { Target Ion } \\
{[\mathrm{m} / \mathrm{z}]}\end{array}$ & $\begin{array}{l}\text { Retention } \\
\text { Time }\end{array}$ & Intensity \\
\hline 1 & Glycan Le-b Tetraose & 99 & 1.48 & 1786271 \\
\hline 2 & Difucosyl-para-lacto- $N$-neohexaose & 74 & 1.53 & $1.72 \mathrm{E}+08$ \\
\hline 3 & $6^{\prime}$-Sialyllactose & 71 & 1.59 & 7849301 \\
\hline 4 & $3^{\prime}$-Sialyl- $N$-acetyllactosamine & 107 & 1.65 & $8.13 \mathrm{E}+08$ \\
\hline 5 & $6^{\prime}$-Sialyllactose & 82 & 1.66 & $1.06 \mathrm{E}+09$ \\
\hline 6 & Oligomannose 6 & 73 & 1.73 & $7.40 \mathrm{E}+07$ \\
\hline 7 & A-Trisaccharide & 70 & 1.84 & $7.65 \mathrm{E}+07$ \\
\hline 8 & iso-B-Pentasaccharide & 73 & 1.88 & 5837818 \\
\hline 9 & 3'-Sialyl Lewis X & 83 & 1.94 & $1.52 \mathrm{E}+08$ \\
\hline 10 & 6'-Sialyllactose & 71 & 1.98 & $2.41 \mathrm{E}+07$ \\
\hline 11 & Glycan Le-b Tetraose & 79 & 2.02 & $1.50 \mathrm{E}+08$ \\
\hline 12 & $4 \beta$-Galactobiose & 74 & 2.1 & $2.34 \mathrm{E}+08$ \\
\hline 13 & iso-B-Pentasaccharide & 97 & 2.15 & $8.74 \mathrm{E}+07$ \\
\hline 14 & Galacto- $N$-biose & 84 & 2.19 & $1.76 \mathrm{E}+08$ \\
\hline 15 & iso-B-Pentasaccharide & 97 & 2.24 & $2.76 \mathrm{E}+07$ \\
\hline 16 & Sialylated tetraose type 2 & 97 & 2.27 & $2.42 \mathrm{E}+07$ \\
\hline 17 & Isoglobotriaose- $\beta-N$ (Acetyl)-Propargyl & 85 & 2.34 & 4713606 \\
\hline 18 & Glycan fucosylated oligosaccharide & 83 & 2.42 & $1.98 \mathrm{E}+07$ \\
\hline 19 & Le-A Trisaccharide & 70 & 2.51 & 2342311 \\
\hline 20 & Unidentified & 91 & 2.57 & $1.81 \mathrm{E}+07$ \\
\hline 21 & Unidentified & 91 & 2.62 & $2.81 \mathrm{E}+07$ \\
\hline 22 & 6-Sialylgalactose & 91 & 2.78 & 4008337 \\
\hline 23 & $3^{\prime}$-Sialyl- $N$-acetyllactosamine & 79 & 7.79 & 2578279 \\
\hline 24 & 3'-Sialyl Lewis X & 105 & 8.06 & 1655128 \\
\hline 25 & iso-B-Pentasaccharide & 206 & 8.68 & 3367370 \\
\hline
\end{tabular}

Table 4. GC-MS analysis of glycosyl composition of exopolymers isolated from Vibrio harveyi (EPS-Psh).

\section{Discussion}

The settlement assay results of the present study indicated the importance of water-soluble cues as settlement inducers for barnacle larvae. The EPSs isolated from P. shioyasakiensis, V. harveyi and Planomicrobium sp. showed better settlement induction rate compared with the control. However, the percentage of larval settlement induced by EPS-Pla was high when compared with EPS-Psh and EPS-Vha (Fig. 1). This indicates that the larval settlement-inducing activity of the exopolymers may differ with the source microbial species ${ }^{31}$. The present results are consistent with previous work that barnacle cyprids depend on water-soluble polymeric cues for larval response due to the absence of substratum-coated $\operatorname{cues}^{27,31}$.

The active substrate selection and settlement of marine invertebrates are induced by cues believed to be chemical in nature ${ }^{28}$. The chemical cues responsible for settlement has been recognized by the chemoreceptors of marine invertebrate larvae ${ }^{32,33}$. Earlier, the role of chemical cues for settlement was reported only for few marine invertebrate larvae, including mud snail Ilyanassa obsoleta ${ }^{34}$, sand dollar Dendraster excentricus ${ }^{35}$, coral-eating nudibranch Phestilla ${ }^{36}$ and the oyster Crassostrea gigas ${ }^{37}$. Induction of larval settlement by bacteria-derived metabolites has been well documented in the literature ${ }^{23}$. For instance, water-soluble exopolymers and bacterial metabolites induced settlement of the tube worm H. elegans ${ }^{25}$.

${ }^{1} \mathrm{H}$ NMR analysis is a powerful tool for chemical fingerprinting and in this study, polymeric samples from different sources were analysed for the presence of different types of chemicals ${ }^{38}$. Results revealed chemical shifts indicating the presence of sugar ring protons, proteins and acetyl groups (Fig. 3). An anomeric proton region in the NMR spectra was revealed through the presence of proton signals between 4.1 and $5.4 \mathrm{ppm}^{39}$. The peaks around $2.2 \mathrm{ppm}$ spectra have been assigned to acetyl amines of hexose or pentose $\mathrm{e}^{40}$. The chemical shift at $3.4 \mathrm{ppm}$ was attributed to exopolymers, proteins, acetyl and succinyl groups ${ }^{41}$. The proton signals at $4.1 \mathrm{ppm}$ were attributed to fucosylated compounds in the EPS samples ${ }^{42}$. The spectral shift at 2.0, 4.4 and $4.6 \mathrm{ppm}$ showed the presence of $N$-acetyl and $N$-acetyllactosamine ${ }^{43}$. The chemical shift at $5.3 \mathrm{ppm}$ was ascribed to tetraose compounds ${ }^{44}$. The proton signals between 3.5 and $4.0 \mathrm{ppm}$ were common in all the three exopolymeric samples. The chemical shift in the particular region was ascribed to N-glycans and linked to mannose compounds ${ }^{45}$.

The biochemical characterization of exopolymers showed that the polysaccharide was the major component and the protein content was lower than the total carbohydrates (Table 2). GC-MS analysis of the glycosyl composition of the exopolymers produced by EPS-Psh, EPS-Vha and EPS-Pla were composed of N-glycans, fucosylated compounds and oligomannose glycans, $\mathrm{N}$-acetyllactosamine (Tables $3-5$ ). The glycans has a complementary function in governing the strength and viscosity of a biofilm matrix produced by bacteria ${ }^{46}$. Previous research has shown that $\mathrm{N}$-glycans, fucosylated oligomannose and oligomannose glycan moiety induce the settlement of $A$. amphitrite cyprids ${ }^{47,48}$. $N$-acetyllactosamine identified in our study has been reported earlier for its settlement-inducing activity of coral larvae Acropora spp. and Agaricia humilis ${ }^{23,24}$. Earlier it has been identified 


\begin{tabular}{|c|c|c|c|c|}
\hline & Glycosyl composition & Target Ion $[\mathrm{m} / \mathrm{z}]$ & Retention Time & Intensity \\
\hline 1 & Glycan Le-b Tetraose & 99 & 1.48 & 1692712 \\
\hline 2 & Difucosyl-para-lacto- $N$-neohexaose & 74 & 1.53 & $1.71 \mathrm{E}+08$ \\
\hline 3 & H-Trisaccharide & 89 & 1.58 & $1.33 \mathrm{E}+07$ \\
\hline 4 & 3'-Sialyl- $N$-acetyllactosamine & 88 & 1.65 & $6.57 \mathrm{E}+08$ \\
\hline 5 & 3'-Sialyl Lewis X & 117 & 1.66 & $1.06 \mathrm{E}+09$ \\
\hline 6 & Sialyl-Lacto- $N$-tetraose & 73 & 1.73 & $1.07 \mathrm{E}+08$ \\
\hline 7 & A-Trisaccharide & 147 & 1.77 & $7.60 \mathrm{E}+07$ \\
\hline 8 & Glycan lacto-N-hexaose & 70 & 1.84 & $8.10 \mathrm{E}+07$ \\
\hline 9 & Galacto- $N$-biose & 73 & 1.88 & 6332569 \\
\hline 10 & 3'-Sialyl Lewis X & 83 & 1.94 & $1.64 \mathrm{E}+08$ \\
\hline 11 & iso-B-Pentasaccharide & 71 & 1.98 & $2.68 \mathrm{E}+07$ \\
\hline 12 & Glycan Le-b Tetraose & 71 & 2.02 & $1.32 \mathrm{E}+08$ \\
\hline 13 & Galacto- $N$-biose & 77 & 2.1 & $2.62 \mathrm{E}+08$ \\
\hline 14 & Galacto- $N$-biose & 97 & 2.15 & $9.96 \mathrm{E}+07$ \\
\hline 15 & 3'-Sialyl Lewis X & 84 & 2.19 & $1.75 \mathrm{E}+08$ \\
\hline 16 & 6'-Sialyllactose & 97 & 2.24 & $3.22 \mathrm{E}+07$ \\
\hline 17 & iso-B-Pentasaccharide & 97 & 2.27 & $2.72 \mathrm{E}+07$ \\
\hline 18 & Glycan Le-Y Tetraose & 84 & 2.31 & 4848386 \\
\hline 19 & Galacto- $N$-biose & 71 & 2.34 & 5502553 \\
\hline 20 & Glycan fucosylated oligosaccharide & 83 & 2.42 & $2.13 \mathrm{E}+07$ \\
\hline 21 & 6'-Sialyllactose & 125 & 2.52 & 2719762 \\
\hline 22 & Unidentified & 91 & 2.57 & $2.18 \mathrm{E}+07$ \\
\hline 23 & A-Trisaccharide & 91 & 2.62 & $3.34 \mathrm{E}+07$ \\
\hline 24 & $3 \alpha, 4 \beta, 3 \alpha$-Galactotetraose & 82 & 2.72 & 1653783 \\
\hline 25 & Not identified & 91 & 2.78 & 4346030 \\
\hline 26 & Oligomannose 1F & 81 & 3.86 & 1072264 \\
\hline 27 & iso-B-Pentasaccharide & 91 & 7.79 & 2131376 \\
\hline 28 & Monogalactosylated N glycan & 207 & 7.86 & 1662071 \\
\hline 29 & Oligomannose 3A & 111 & 8.68 & 3543469 \\
\hline 30 & $\mathrm{~N}$-acetyllactosamine & 206 & 11.51 & 3129848 \\
\hline
\end{tabular}

Table 5. GC-MS analysis of glycosyl composition of exopolymers isolated from Planomicrobium sp. (EPS-Psh).

that exogenous polysaccharides induced larval settlement and metamorphosis through mannose-binding receptors in spirorbids, ascidians and corals ${ }^{49-51}$. Furthermore, transcriptomics and proteomics studies revealed the presence of Malectin-A and mannose-binding receptors in A. amphitrite cyprid stage ${ }^{52,53}$. Therefore, the results of this study suggest that $\mathrm{N}$-glycans and oligomannose-containing exogenous polysaccharides could bind to the mannose-binding receptors of larvae and induce larval attachment.

FT-IR functional group analysis of crude EPS indicated the presence of carbohydrates, pyranose, mannose and uronic acids (Fig. 6). The presence of these compounds in microbial EPS has been reported previously ${ }^{54-57}$. The peak around $3407-3414 \mathrm{~cm}^{-1}$ and $2926-2929 \mathrm{~cm}^{-1}$ correspond to hydroxyl and $\mathrm{CH}_{2}$ groups respectively ${ }^{58,59}$. The peak around 1421-1424 $\mathrm{cm}^{-1}$ indicated the presence of a $-\mathrm{COO}^{-}$group ${ }^{40}$. Further, the peaks at around $1127-1147 \mathrm{~cm}^{-1}$ showed the presence of pyranose, uronic acid and o-acetyl ester linkage bonds ${ }^{54,57}$. The absorption peak around $500-650 \mathrm{~cm}^{-1}$ was attributed to the presence of pyranose rings ${ }^{56}$.

$\mathrm{XRD}$ analysis revealed the crystalline nature of polymers. EPSs were mostly amorphous in nature, which was reported previously for Vibrio parahaemolyticus, Bacillus licheniformis B22 and Scenedesmus sp. SB1 ${ }^{40,60,61}$. Since very few pieces of evidence are available for the X-ray diffraction analysis of exopolymers, results obtained in this study will further enhance our knowledge of the properties of exopolymers isolated from marine biofilms. The SEM analysis is commonly used to study the surface morphology of exopolymers. The surface features of EPS isolated in the present study exhibit similar morphological characteristics of irregular and aggregated particles as described earlier ${ }^{62}$.

In conclusion, the results of this study indicated the ecological role of $\mathrm{N}$-acetyl, $\mathrm{N}$-glycans and oligomannose present in exopolymers of marine bacteria. Further, the compounds identified from the marine bacterial exopolymers were similar to compounds reported from the settlement-inducing protein complex (SIPC) of A. amphitrite and coralline algal cell wall polysaccharides. Hence, the present study suggests that the cues for larval settlement may possess some kind of similarity in chemical composition irrespective of origin. Further research focusing on the structural characterization of biofilm exopolymers and larval binding receptors will provide more insights into the larval settlement process on hard substrates in marine ecosystems. 

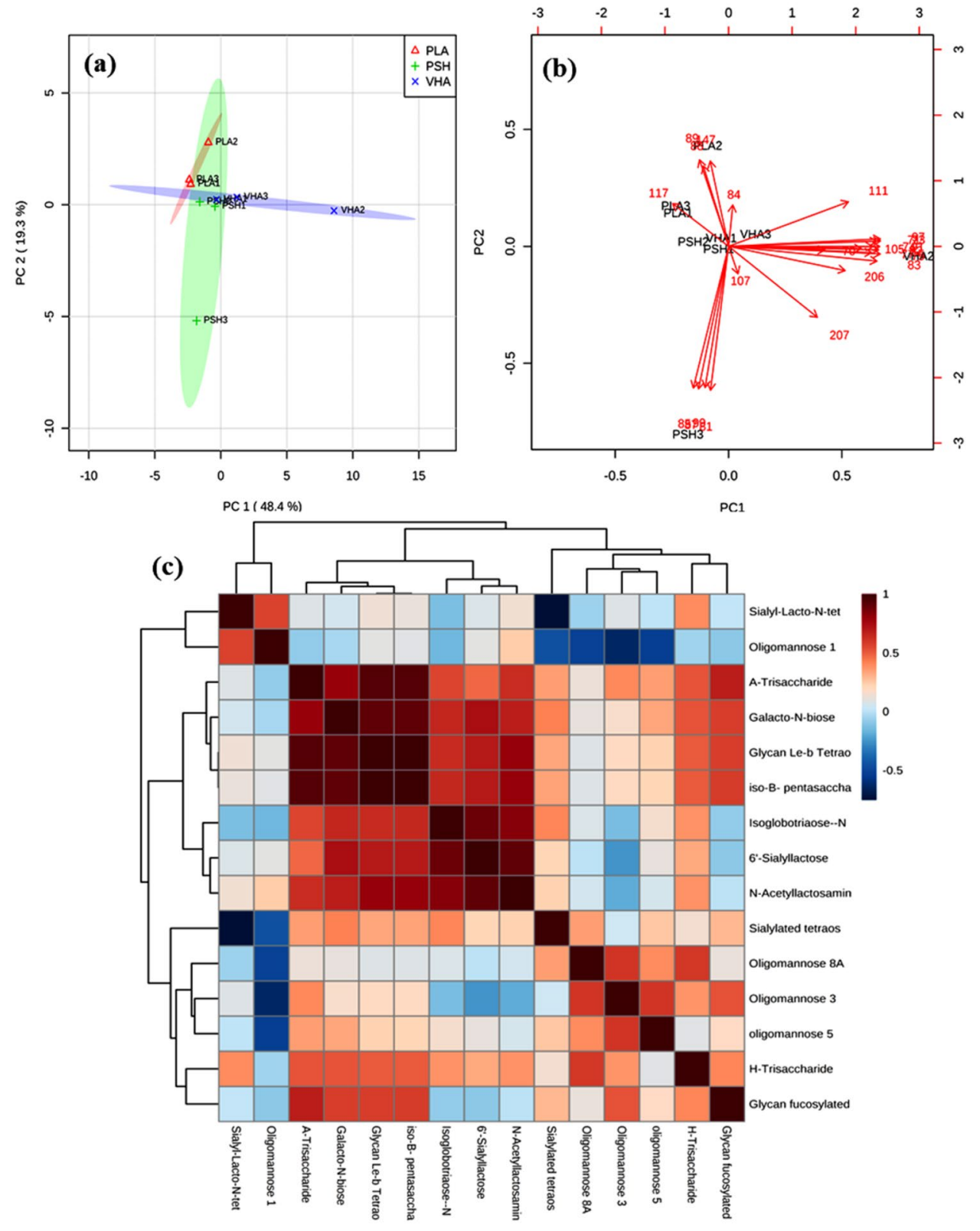

Figure 5. Principal component analysis of EPS isolated from Pseudoalteromonas shioyasakiensis, Vibrio harveyi and Planomicrobium sp. (a) PC1 vs PC2 2D scores plot and (b) PC1 vs PC2 biplots. (c) The correlation heat map analysis of EPS-Psh, EPS-Vha and EPS-Pla.

\section{Materials and Methods}

Barnacle larval rearing for settlement assay. Adult barnacles (A. amphitrite) attached to rocky substrates were collected from the Obhur Creek near the King Abdulaziz University marine station. Adult organisms along with the substrate were maintained in seawater at an ambient temperature $\left(28^{\circ} \mathrm{C}\right)$. The barnacles were exposed to air for less than an hour to induce nauplii release. The nauplii released were collected using a hand net $(80 \mu \mathrm{m})$ and maintained in a $2 \mathrm{~L}$ polypropylene aquarium containing $0.7 \mu \mathrm{m}$ filtered seawater (FSW). The larvae were fed Chaetoceros calcitrans at a density of $2 \times 10^{5}$ cells ml $\mathrm{m}^{-1}$. The photoperiod of $12: 12 \mathrm{~h}$ light and the dark cycle were maintained during cyprid culture. Water was changed daily and renewed with fresh microalgal diet. Nauplii stages were checked under a stereomicroscope (Leica S6E) until the cyprid stage was noticed (5-6 days). Cyprids were collected from the aquarium using a Pasteur pipette and used for settlement studies.

Extraction and purification of exopolymers. Biofilm-forming bacteria were isolated from natural biofilms that developed on aquaculture cage nets submerged in the Obhur Creek, Central Red Sea. P. shioyasakiensis (NCBI GenBank accession number: KY224086), V. harveyi (NCBI GenBank accession number: KY266820) and Planomicrobium sp. (NCBI GenBank accession number: KY224087) were the dominant biofilm bacteria isolated from the cage nets ${ }^{63}$. EPSs were extracted from the marine bacteria by following the method of Zhang et 


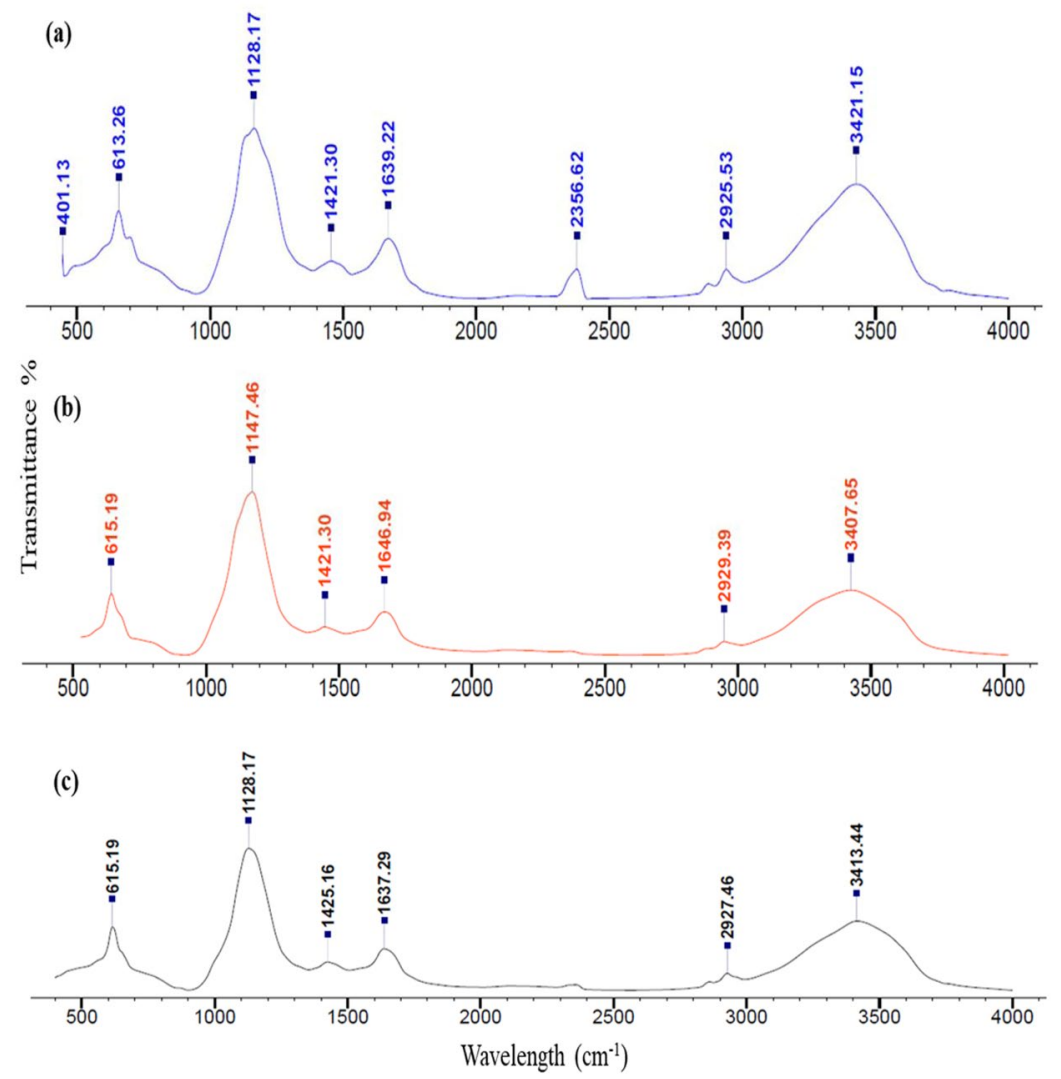

Figure 6. Fourier-transform infrared (FT-IR) spectroscopy analysis of EPS isolated from (a) Pseudoalteromonas shioyasakiensis, (b) Vibrio harveyi and (c) Planomicrobium sp.

\begin{tabular}{|l|l|l|}
\hline EPS & Crystalline phase & Amorphous phase \\
\hline EPS-Psh & 24 & 76 \\
\hline EPS-Vha & 22 & 88 \\
\hline EPS-Pla & 23 & 77 \\
\hline
\end{tabular}

Table 6. Crystalline and amorphous phase values of EPS calculated using crystalline index from XRD analysis data (values in percentage).

$a l .{ }^{64}$ with few modifications. The bacteria were cultured in modified seawater nutrient broth (peptone $10 \mathrm{~g}$, beef extract $10 \mathrm{~g}$, sodium chloride $5 \mathrm{~g}, 0.2 \mu \mathrm{m}$ FSW $1 \mathrm{~L}$ ) at an ambient temperature of $25^{\circ} \mathrm{C}$ for 2 days. The bacterial cultures were centrifuged at $10000 \times g$ at $4{ }^{\circ} \mathrm{C}$ for $20 \mathrm{~min}$. The bacterial pellets were removed and the supernatants were filtered through nitrocellulose membrane filter $(0.45 \mu \mathrm{m})$. The filtered supernatants were used for EPS extraction. EPSs were precipitated by adding equal volume of ice-cold absolute ethanol and refrigerated at $4{ }^{\circ} \mathrm{C}$ for $48 \mathrm{~h}$. The precipitated crude EPSs were collected from the medium and washed with double distilled water and freeze-dried. The freeze-dried crude EPSs were purified using dialysis membrane (12-14 kDa cut-off). The crude EPSs were dialysed against double distilled water overnight. The purified EPSs were freeze-dried and used for characterization and bioassays. The isolated EPSs were then named as EPS-Psh (P. shioyasakiensis), EPS-Vha (V. harveyi) and EPS-Pla (Planomicrobium sp.). The total carbohydrate content of the EPSs was determined by the phenol-sulphuric acid assay using D-glucose as a standard solution ${ }^{65}$. The total protein content was measured by using the protein quantification assay (Roti-Quant, Carl Roth $\mathrm{GmbH}$ ) according to the methods described by Bradford ${ }^{66}$ (1976). Bovine serum albumin (99.8\%) crystals were used as a protein standard and the assay was carried out in 96-microwell culture plates ${ }^{67}$.

Fluorescence microscopy imaging of biofilm. In order to confirm the biofilm-forming ability of the bacteria strains, the biofilms of P. shioyasakiensis, $V$. harveyi and Planomicrobium sp. were grown in gamma-sterilized crystal grade polystyrene 24 -well cell culture plates (SPL Life Sciences) for $24 \mathrm{~h}$ under static conditions at $28^{\circ} \mathrm{C}$. After $24 \mathrm{~h}$, the broth was removed and the wells were slightly rinsed with $0.2 \mu \mathrm{m}$ FSW to remove planktonic bacterial cells. For nucleus staining, the biofilm bacterial cells were stained with $50 \mu \mathrm{l}$ of $0.01 \%$ DAPI solution (4',6-diamidino-2-phenylindole) and incubated for $5 \mathrm{~min}$ in the dark. After incubation, the wells were washed with $1 \mathrm{x}$ PBS and dried before imaging. Images were collected using fluorescence microscope EVOS 

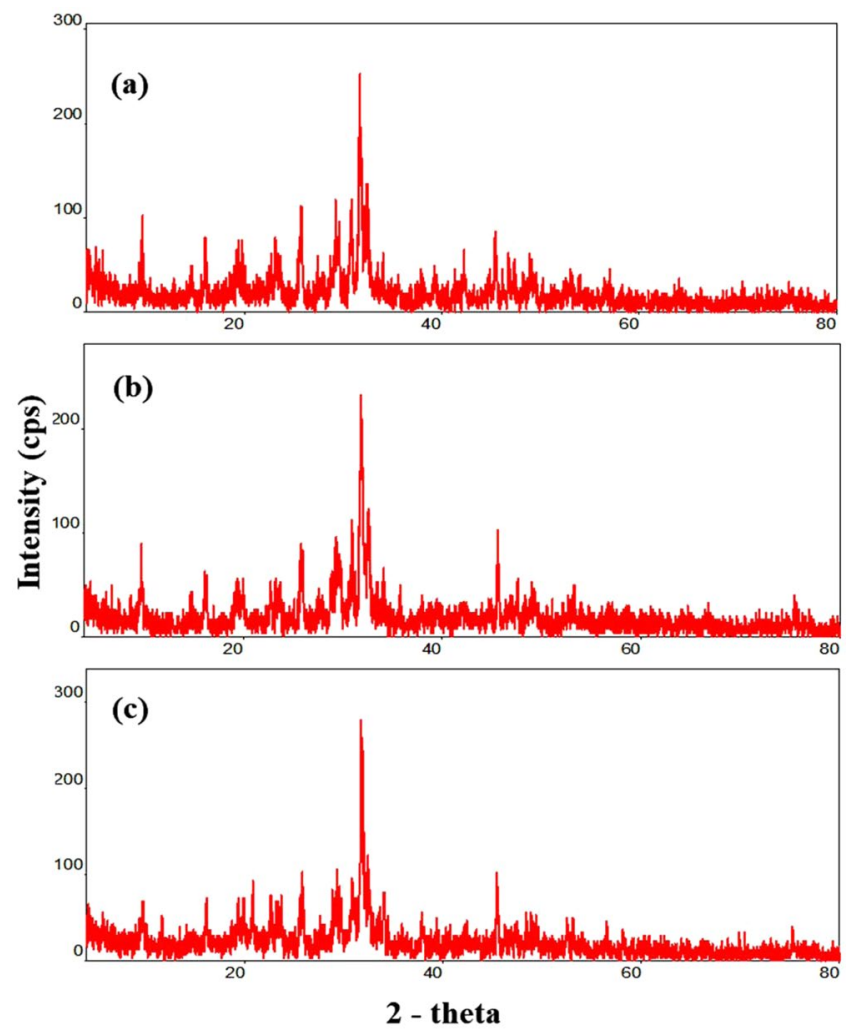

Figure 7. X-ray diffraction analysis of EPS isolated from (a) Pseudoalteromonas shioyasakiensis, (b) Vibrio harveyi and (c) Planomicrobium sp.

FL Cell Imaging System (Thermo Fisher Scientific, CA) equipped with RFP (red fluorescence), GFP (green fluorescence) and DAPI light cubes.

Larval toxicity assay. The EPS toxicity to barnacle larvae was assessed by treating the EPS suspension against stage III nauplii. The EPS (EPS-Psh, EPS-Vha and EPS-Pla) stock solutions were prepared in FSW at a concentration of $10 \mathrm{mg} \mathrm{ml}^{-1}$. The assay was performed by adding 10 nauplii to 12 -well plates containing $3 \mathrm{ml}$ of different EPS concentrations $(0,250,500,750 \mu \mathrm{g} \mathrm{L}-1)$ in $0.2 \mu \mathrm{m}$ FSW. The experiment was carried out (in replicates, $\mathrm{n}=4$ ) for $48 \mathrm{~h}$ in a climate-controlled walk-in environmental chamber at an ambient temperature of $28^{\circ} \mathrm{C}$.

Larval settlement assay. Barnacle larval settlement assay was performed by adding 10 cyprids to six-well plates (Falcon) containing $10 \mathrm{ml}$ of different EPS concentrations $\left(0,250,500,750 \mu \mathrm{g} \mathrm{L}^{-1}\right)$ in $0.2 \mu \mathrm{m}$ FSW. The experiment was carried out (in replicates, $\mathrm{n}=6$ ) for $48 \mathrm{~h}$ in a climate-controlled walk-in environmental chamber at an ambient temperature of $28^{\circ} \mathrm{C}$. After 24 and $48 \mathrm{~h}$, the number of settled and metamorphosed cyprids in the multi-well plates was checked under a stereomicroscope (Leica S6E) (Supplementary Figure S1). Data obtained from larval settlement assay were subjected to two-way ANOVA to understand the variations between treatments. Concentration of EPS and larval settlement observation time ( 24 and $48 \mathrm{~h}$ ) were used as factors. For statistical tests, $\mathrm{P}<0.05$ was considered as significant. Also, the $\mathrm{EC}_{50}$ values (the concentration in which $50 \%$ settlement induction was observed) were calculated based on regression analysis between the EPS concentration and percentage of settlement observed.

${ }^{1} \mathrm{H}$ NMR analysis. For proton NMR analysis, $30 \mathrm{mg}$ of lyophilized EPS samples was dissolved in $500 \mu \mathrm{l}$ of deuterated DMSO and kept in a $5 \mathrm{~mm}$ NMR tube. The NMR spectra were recorded at $300 \mathrm{~K}$ using a Bruker AVANCE III $600 \mathrm{MHz}$ equipped with a CryoProbe. The chemical shifts were expressed in parts per million (ppm) relative to internal chemical shift reference, 4-dimethyl-4-silapentane-1-sulfonic acid. The NMR peaks obtained were integrated and picked by Bruker Topspin 3.2 software.

GC-MS analysis. Glycosyl composition of the exopolymers from three marine biofilm bacteria was carried out as described by Hammi et al..$^{68}$ with little modifications. The purified EPSs $(4 \mathrm{mg})$ added with $50 \mu \mathrm{L}$ of myo-inositol $\left(2 \mathrm{mg} \mathrm{mL}^{-1}\right.$, internal standard) were hydrolysed by $2 \mathrm{M}$ trifluoroacetic acid at $90^{\circ} \mathrm{C}$ for $2 \mathrm{~h}$ in a sealed glass tube. Then, the hydrolysed lysates were freeze-dried. Trimethylsilyl derivatives were prepared by adding $150 \mu \mathrm{L}$ of pyridine and $150 \mu \mathrm{L}$ of $N$, O-bis trimethylsilyl trifluoroacetamide to the dried samples. The samples were heated to $80^{\circ} \mathrm{C}$ for $30 \mathrm{~min}$ and then evaporated to dryness. The residues were dissolved in $750 \mu \mathrm{L}$ of dichloromethane and trimethylsilyl derivatives were analysed by a $7000 \mathrm{C}$ triple quadrupole gas chromatography-mass 
a

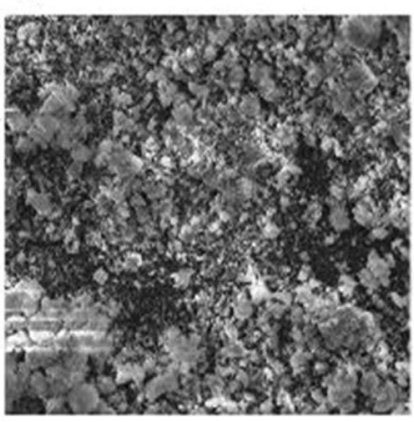

d

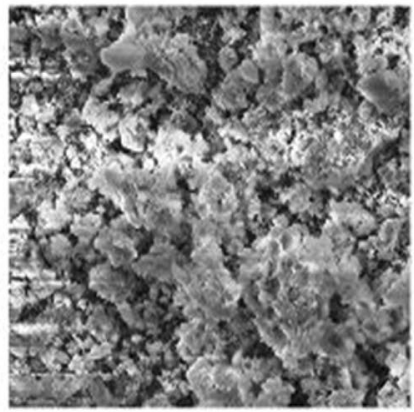

g

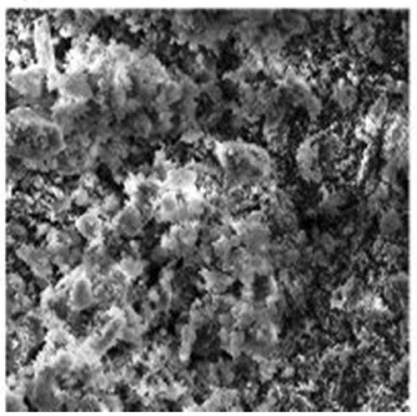

b

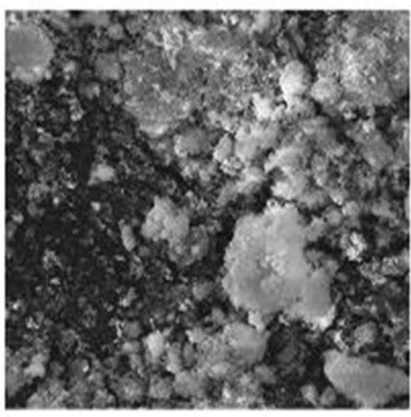

e

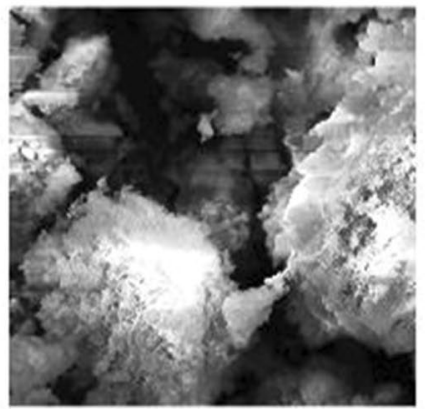

h

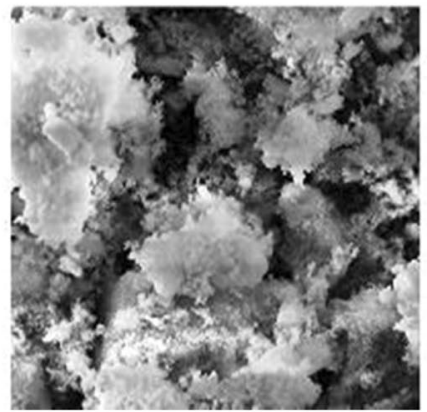

C

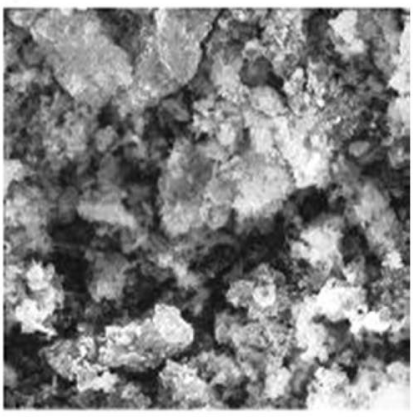

f

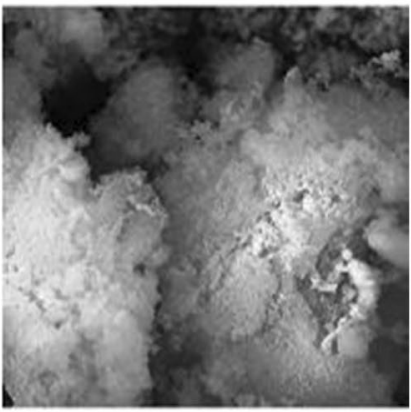

i

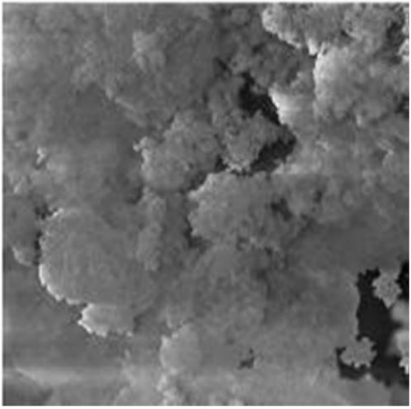

Figure 8. Scanning electron microscopy image of EPS isolated from Pseudoalteromonas shioyasakiensis (a-c), Vibrio harveyi (d-f) and Planomicrobium sp. (g-i).

spectrometry system (Agilent Technologies). The instrument was equipped with a high-sensitivity extractor ion source and a triple-axis HED-EM detector which can identify trace components even in complex mixtures at the femtogram level. For statistical tests, the samples were analysed by GC-MS in triplicate. The triplicate samples of EPS-Psh were labelled as Psh1, Psh2 and Psh3. Similarly, the EPS-Vha and EPS-Pla samples were named as Vha1, Vha2, Vha3 and Pla1, Pla2, Pla3 respectively.

The Agilent MassHunter, Openchrom (Dalton, Lablicate and Scientific community), Automated Mass Spectral Deconvolution and Identification System (AMDIS v2.73), NIST MS search, NIST glycan MS library (National Institute of Standards and Technology, USA), MetaboAnalyst 4.0 were used for mass spectral acquisition, peak processing, spectral deconvolution, compound identification, data visualization and statistical analysis. GC-MS spectra for the exopolymers samples were acquired using an Agilent MassHunter software and the data were exported (.mzdata.xml file) to OpenChrom mass spectral analysis software for peak integration and active peak identification. The MS peaks were deconvoluted using AMDIS software; the retention indices were searched against NIST MS library and NIST glycan MS library search for compound identification. The compounds from the top hit list of the library search were reported. The statistical analysis for the MS peak list and intensity data were performed using MetaboAnalyst 4.0 software. The MS peak list data were uploaded as a CSV (.csv) file; a further quality check of data and normalization by autoscaling were done. The normalized data were used for PCA and correlation heatmap analysis.

FT-IR analysis. All the three EPSs were subjected to functional group analysis using Fourier-transform infrared (FT-IR) spectroscopy. Three milligrams of lyophilized EPS samples was pressed in KBr pellets and the spectral wavelength was recorded in the range of $4000-400 \mathrm{~cm}^{-1}$ with a resolution of $4 \mathrm{~cm}^{-1}$ using an FT-IR spectrometer 
(Perkin Elmer) ${ }^{69}$. The FT-IR were analysed and the functional groups were interpreted using KnowItAll(R) Informatics System from Bio-Rad Laboratories. The FT-IR spectra of all the EPSs were stacked together to elucidate similarities in spectral regions.

X-ray diffraction analysis of EPSs. Powder XRD analysis is extensively used for the characterization of polymers and is useful for studying the crystalline nature of exopolymers derived from different origins ${ }^{68}$. EPSs (EPS-Psh, EPS-Vha and EPS-Pla) were analysed by XRD using a multipurpose X-ray diffraction system (Rigaku Ultima IV XRD) with $2 \Theta$ ranging from 2 to $80^{\circ}$ at $25^{\circ} \mathrm{C}$. The irradiated length and specimen length were $10 \mathrm{~mm}$, with a receiving slit size of $0.2 \mathrm{~mm}$ at a $285 \mathrm{~mm}$ goniometer radius. The distance from the focus to divergence slit was $100 \mathrm{~mm}$. Lyophilized EPS samples were mounted on quartz substrata, and the intensity peaks of diffracted $\mathrm{X}$-rays were continuously recorded with a scan step time of $1 \mathrm{~s}$; d-spacings appropriate to the diffracted X-rays at each $\Theta$ value were calculated from Bragg's law (Eq. 1).

$$
d=\lambda / 2 \sin \Theta
$$

where

$d$ is the interplanar distance,

$\lambda$ is the incident wavelength and

$\Theta$ is the scattering angle measured from the incident beam.

The crystallinity index $\left(\mathrm{CI}_{\mathrm{xrd}}\right)$ was calculated as the ratio of the crystalline phase peak areas to the sum of the crystalline peak areas and the amorphous profile (Eq. 2) ${ }^{70}$.

$$
\mathrm{CI}_{\mathrm{xrd}}=\Sigma A_{\text {crystal }} / \Sigma A_{\text {crystal }}+\Sigma A_{\text {amorphous }}
$$

SEM analysis of EPS. The surface morphology of EPSs was identified using scanning electron microscopy (VEGA3 TESCAN) with an accelerating voltage of $20 \mathrm{kV}$ and $10 \mathrm{~mm}$ working distance. Lyophilized EPS samples were mounted on the metal and gold sputtered prior to imaging. SEM micrographs were captured at 500x, $2.0 \mathrm{kx}$ and $5.0 \mathrm{kx}$ magnification ${ }^{71}$.

\section{Data availability}

All generated data used for the analysis are available upon request from the corresponding author.

Received: 29 August 2019; Accepted: 9 November 2019;

Published online: 28 November 2019

\section{References}

1. Freckelton, M. L., Nedved, B. T. \& Hadfield, M. G. Induction of invertebrate larval settlement; different bacteria, different mechanisms? Sci Rep 7, 42557 (2017).

2. Rodriguez, S. R., Ojeda, F. P. \& Inestrosa, N. C. Settlement of benthic marine invertebrates. Mar Ecol Prog Ser 97, 193-207 (1993).

3. Tegtmeyer, K. \& Rittschof, D. Synthetic peptide analogs to barnacle settlement pheromone. Peptides 9, 1403-1406 (1988).

4. Kitamura, H., Kitahara, S. \& Koh, H. B. The induction of larval settlement and metamorphosis of two sea urchins, Pseudocentrotus depressus and Anthocidaris crassispina, by free fatty acids extracted from the coralline red alga Corallina pilulifera. Mar Biol 115, 387-392 (1993).

5. Lam, C., Harder, T. \& Qian, P. Induction of larval settlement in the polychaete Hydroides elegans by extracellular polymers of benthic diatoms. Mar Ecol Prog Ser 286, 145-154 (2005).

6. Huang, Y. L., Dobretsov, S., Ki, J. S., Yang, L. H. \& Qian, P. Y. Presence of acyl-homoserine lactone in subtidal biofilm and the implication in larval behavioral response in the polychaete Hydroides elegans. Microb Ecol 54, 384-392 (2007).

7. Zardus, J. D., Nedved, B. T., Huang, Y., Tran, C. \& Hadfield, M. G. Microbial biofilms facilitate adhesion in biofouling invertebrates. Biol Bull 214, 91-98 (2008).

8. Elbourne, P. D., Veater, R. A. \& Clare, A. S. Interaction of conspecific cues in Balanus amphitrite Darwin (Cirripedia) settlement assays: Continued argument for the single-larva assay. Biofouling 24, 87-96 (2008).

9. Sneed, J. M., Sharp, K. H., Ritchie, K. B. \& Paul, V. J. The chemical cue tetrabromopyrrole from a biofilm bacterium induces settlement of multiple Caribbean corals. Proc Biol Sci 281, 20133086 (2014).

10. Tebben, J. et al. Chemical mediation of coral larval settlement by crustose coralline algae. Sci Rep 5, 10803 (2015)

11. Le, D. V., Young, T., Alfaro, A. C., Watts, E. \& King, N. Effect of neuroactive compounds on larval metamorphosis of New Zealand geoduck (Panopea zelandica). Aquac Res 48, 3080-3090 (2016).

12. Wingender J., Neu T. R., Flemming H. C. What are Bacterial Extracellular Polymeric Substances? In: Microbial Extracellular Polymeric Substances. Springer, Heidelberg, pp. 1-19 (1999).

13. Decho, A. W. Microbial exopolymer secretions in ocean environments: their role(s) in food webs and marine processes. Oceanogr Mar Biol Ann Rev 28, 73-153 (1990).

14. Liu, Y. Q., Liu, Y. \& Tay, J. H. The effects of extracellular polymeric substances on the formation and stability of biogranules. Appl Microbiol Biotechnol 65, 143-148 (2004).

15. Dominiak, D. M., Nielsen, J. L. \& Nielsen, P. H. Extracellular DNA is abundant and important for microcolony strength in mixed microbial biofilms. Environ Microbiol 13, 710-721 (2011).

16. Decho, A. W. \& Gutierrez, T. Microbial Extracellular Polymeric Substances (EPSs) in Ocean Systems. Front Microbiol 8, 922, https:// doi.org/10.3389/fmicb.2017.00922 (2017).

17. Liang, Z., Li, W., Yang, S. \& Du, P. Extraction and structural characteristics of extracellular polymeric substances (EPS), pellets in autotrophic nitrifying biofilm and activated sludge. Chemosphere 81, 626-63 (2010).

18. Jiao, Y. et al. Characterization of extracellular polymeric substances from acidophilic microbial biofilms. Appl Environ Microbiol 76, 2916-2922 (2010).

19. Camacho-Chab, J. C. et al. Implications of extracellular polymeric substance matrices of microbial habitats associated with coastal aquaculture system. Water $\mathbf{8 ,} 369$ (2016).

20. Sutherland, I.W. Extracellular microbial polysaccharides: Microbial exopolysaccharide synthesis. American Chemical Society, Washington, DC, pp. 40-57 (1977). 
21. Ramirez-Mora, T., Retana-Lobo, C. \& Valle-Bourrouet, G. Biochemical characterization of extracellular polymeric substances from endodontic biofilms. PLoS ONE 13, 0204081 (2018).

22. Szewzyk, U. et al. Relevance of the exopolysaccharide of marine Pseudomonas sp. strain S9 for the attachment of Ciona intestinalis larvae. Mar Ecol Prog Ser 75, 259-265 (1991).

23. Hadfield, M. G. \& Paul, V. J. Marine chemical ecology: Natural chemical cues for settlement and metamorphosis of marineinvertebrate larvae. CRC Press, Florida, pp. 431-463 (2001).

24. Morse, D. E. \& Morse, A. N. C. Enzymatic characterization of the morphogen recognized by Agaricia humilis (Scleractinian Coral) larvae. Biol Bull 181, 104-122 (1991).

25. Lau, S. C. K., Harder, T. \& Qiaz, P. Induction of larval settlement in the serpulid polychaete Hydroides elegans (Haswell): Role of bacterial extracellular polymers. Biofouling 19, 197-204 (2003)

26. Patil, J. \& Anil, A. C. Influence of diatom exopolymers and biofilms on metamorphosis in the barnacle Balanus amphitrite. Mar Ecol Prog Ser 301, 231-245 (2005).

27. Khandeparker, L., Anil, A. C. \& Raghukumar, S. Relevance of biofilm bacteria in modulating the larval metamorphosis of Balanus amphitrite. FEMS Microbiol Ecol 58, 425-438 (2006)

28. Pawlik, J. R. Chemical ecology of the settlement of benthic marine invertebrates. Oceanogr Mar Biol Ann Rev 30, 273-335 (1992).

29. Satheesh, S. \& Wesley, S. G. Breeding Biology of the Barnacle Balanus amphitrite Darwin (Crustacea: Cirripedia): Influence of environmental factors in a tropical coast. J Mar Biol Assoc UK 89, 1203-1208 (2009).

30. Al- Aidaroos, A. M. \& Satheesh, S. Larval development and settlement of the barnacle Amphibalanus amphitrite from the Red Sea: Influence of the nauplii hatching season. Oceanol. Hydrobiol Stud 43, 170-177 (2014).

31. Khandeparker, L., Anil, A. C. \& Raghukumar, S. Factors regulating the production of different inducers in Pseudomonas aeruginosa with reference to larval metamorphosis in Balanus amphitrite. Aquat Microb Ecol 28, 37-54 (2002).

32. Knight-Jones, E. W. \& Crisp, D. J. Gregariousness in barnacles in relation to the fouling of ships and to antifouling research. Nature 171, 1109-1110 (1953).

33. Crisp, D. J. Chemoreception in marine organisms: Factors influencing the settlement of marine invertebrate larvae. Academic Press, New York, pp. 177-265 (1974).

34. Scheltema, R. S. Metamorphosis of the veliger larvae of Nassarius obsoletus (Gastropoda) in response to bottom sediment. Biol Bull 120, 92-109 (1961)

35. Highsmith, R. C. Induced settlement and metamorphosis of sand dollar (Dendraster excentricus) larvae in predator free sites: adult sand dollar beds. Ecology 63, 329-337 (1982).

36. Hadfield, M. G. \& Scheuer, D. Evidence for a soluble metamorphic inducer in Phestilla: Ecological, chemical and biological data. Bull Mar Sci 37, 556-566 (1985).

37. Coon, S. L., Fitt, W. K. \& Bonar, D. B. Competence and delay of metamorphosis in the pacific oyster Crassostrea gigas. Mar Biol 106, 379-387 (1990)

38. Diehl, B. NMR spectroscopy in pharmaceutical analysis: NMR applications for polymer characterisation. Elsevier, pp. 157-180 (2008).

39. Elnahas, M. O. et al. Isolation, Characterization and Bioactivities of an Extracellular Polysaccharide Produced from Streptomyces sp. MOE6. Molecules 22, 1396, https://doi.org/10.3390/molecules22091396 (2017).

40. Kavita, K., Mishra, A. \& Jha, B. Isolation and physico-chemical characterisation of extracellular polymeric substances produced by the marine bacterium Vibrio parahaemolyticus. Biofouling 27, 309-317 (2011).

41. Gonzalez-Gil, G., Thoma, L., Emwas, A. H., Lens, P. N. L. \& Saikaly, P. E. NMR and MALDI-TOF MS based characterization of exopolysaccharides in anaerobic microbial aggregates from full-scale reactors. Sci Rep 5, 14316 (2015).

42. Hokke, C. H., Kamerling, J. P., Gijs, W. K., van, D. \& Vliegenthart, J. F. G. Determination of the branch location of extra $\mathrm{N}$-acetyllactosamine units in sialo N-linked tetraantennary oligosaccharides. FEBS Lett 286, 18-24 (1991).

43. Vliegenthart, J. F. G., Herman, H. V. \& Lambertus, D. The applicability of 500-mhz high-resolution ${ }^{1} \mathrm{H}-\mathrm{NMR}$ spectroscopy for the structure determination of carbohydrates derived from glycoproteins. Pure Appl Chem 53, 45-77 (1981).

44. Mbawala, A., Al Mahmood, S., Loppinet, V. \& Bonaly, R. Acetolysis and ${ }^{1} \mathrm{H}$ NMR studies on mannans isolated from very flocculent and weakly flocculent cells of Pichia pastoris IFP 206. Microbiology 136, 1279-1284 (1990).

45. Mulloy, B., Hart, G. W. \& Stanley, P. Structural Analysis of Glycans. In: Varki. A., R. D. Cummings \& J. D. Esko (eds). Essentials of Glycobiology. Cold Spring Harbor Laboratory Press, Cold Spring Harbor (NY), 47 (2009).

46. Sheppard, D. C. \& Howell, P. L. Biofilm Exopolysaccharides of Pathogenic Fungi: Lessons from Bacteria. J Biol Chem 291, 12529-12537, https://doi.org/10.1074/jbc.R116.720995 (2016).

47. Matsumura, K., Mori, S., Nagano, M. \& Fusetani, N. Lentil lectin inhibits adult extract-induced settlement on the barnacle, Balanus amphitrite. J Exp Biol 280, 213-219 (1998).

48. Pagett, H. E. et al. Structural characterisation of the N-glycan moiety of the barnacle settlement-inducing protein complex (SIPC). J Exp Biol 215, 1192-1198 (2012)

49. Maki, J. \& Mitchell, R. Involvement of lectins in the settlement and metamorphosis of marine invertebrate larvae. Bull Mar Sci 37, 675-683 (1985)

50. Davidson, B. \& Swalla, B. A novel C-type lectin regulating cell growth, cell adhesion and cell differentiation of the multipotent epithelium in budding tunicates. Development 128, 3339-47 (2001).

51. Grasso, L. C. et al. Microarray analysis identifies candidate genes for key roles in coral development. BMC Genom 9, 540 (2008).

52. Chen, Z. F. et al. Toward an understanding of the molecular mechanisms of barnacle larval settlement: a comparative transcriptomic approach. PLoS ONE 6, e22913 (2011)

53. Zhang, C. et al. Quantitative proteomics study of larval settlement in the barnacle Balanus amphitrite. PLoS ONE 9, 88744, https:// doi.org/10.1371/journal.pone.0088744 (2014).

54. Kazy, S. K., Sar, P., Singh, S. P., Sen, A. K. \& D’Souza, S. F. Extracellular polysaccharides of a copper-sensitive and a copper-resistant Pseudomonas aeruginosa strain: synthesis, chemical nature and copper binding. World J Microbiol Biotechnol 18, 583-588 (2002).

55. Wang, J. \& Somasundaran, P. Study of galactomannose interaction with solids using AFM, IR and allied techniques. J Colloid Interf Sci 309, 373-383 (2007)

56. Yang, J. L., Glenn, S. C., Bao, W. Y. \& Kitamura, H. Induction of metamorphosis of pediveliger larvae of the mussel Mytilus galloprovincialis Lamarck, 1819 using neuroactive compounds, $\mathrm{KCl}, \mathrm{NH}_{4} \mathrm{Cl}$ and organic solvents. Biofouling 24, 461-470 (2008).

57. Liu, C. et al. Characteristics and Antitumor Activity of Morchella esculenta Polysaccharide Extracted by Pulsed Electric Field. Int $J$ Mol Sci 17, 986, https://doi.org/10.3390/ijms17060986 (2016).

58. Iyer, A., Mody, K. \& Jha, B. Characterization of an exopolysaccharide produced by a marine Enterobacter cloacae. Indian J Exp Biol 43, 467-514 (2005).

59. Sahoo, G. \& Khandeparker, L. Role of epibiotic diatoms isolated from the barnacle shell in the cyprid metamorphosis of Balanus amphitrite. Hydrobiologia 822, 129 (2018).

60. Dogan, N. M., Doganli, G. A., Dogan, G. \& Bozkaya, O. Characterization of extracellular polysaccharides (eps) produced by thermal Bacillus and determination of environmental conditions affecting exopolysaccharide production. Int J Environ Res 9, 1107-1116, https://doi.org/10.22059/IJER.2015.998 (2015).

61. Angelaalincy, M. et al. Enhanced extracellular polysaccharide production and self-sustainable electricity generation for PAMFCs by Scenedesmus sp. SB1. ACS Omega 2, 3754-3765 (2017). 
62. Zhang, P. et al. Preparation and biological activities of an extracellular polysaccharide from Rhodopseudomonas palustris. Int J Biol Macromol 131, 933-940, https://doi.org/10.1016/j.ijbiomac.2019.03.139 (2019).

63. Balqadi, A. A., Salama, A. J. \& Satheesh, S. Microfouling development on artificial substrates deployed in the central Red Sea. Oceanologia 60, 219-231 (2018).

64. Zhang, L. et al. Antioxidant activity of an exopolysaccharide isolated from Lactobacillus plantarum C88. Int J Biol Macromol 54, 270-275 (2013).

65. Dubois, M. et al. Colorimetric method for determination of sugars and related substances. Anal Chem. 28, 350-356 (1956).

66. Bradford, M. M. A rapid and sensitive method for the quantitation of microgram quantities of protein utilizing the principle of protein-dye binding. Anal Biochem 72, 248-254 (1976)

67. Chial, H. J. \& Splittgerber, A. G. A comparison of the binding of Coomassie brilliant blue to proteins at low and neutral pH. Anal Biochem 213, 362-369 (1993).

68. Hammi, K. M. et al. GC-EI-MS identification data of neutral sugars of polysaccharides extracted from Zizyphus lotus fruit. Data Brief 18, 680-683 (2018).

69. Kavita, K., Singh, V. K., Mishra, A. \& Jha, B. Characterisation and anti-biofilm activity of extracellular polymeric substances from Oceanobacillus iheyensis. Carbohydr Polym 101, 29-35 (2014).

70. Ricou, P., Pinel, E. \& Juhasz, N. Temperature experiments for improved accuracy in the calculation of polyamide-11 crystallinity by X-ray diffraction. Adv X-ray Anal 48, 171-175 (2005).

71. Kanamarlapudi, S. L. R. K. \& Muddada, S. Characterization of exopolysaccharide produced by Streptococcus thermophilus CC30. BioMed Res Int 4201809, 1-11 (2017).

\section{Acknowledgements}

This project was funded by the Deanship of Scientific Research (DSR), King Abdulaziz University, Jeddah, under grant No. (D-011-150-1440). The authors, therefore, gratefully acknowledge the DSR for technical and financial support.

\section{Author contributions}

S.S. conceived and designed the experiments, and reviewed and edited the manuscript. A.S. performed the experiments and wrote the manuscript. S.S., and A.S. analysed the data and were involved in funding acquisition.

\section{Competing interests}

The authors declare no competing interests.

\section{Additional information}

Supplementary information is available for this paper at https://doi.org/10.1038/s41598-019-54294-9.

Correspondence and requests for materials should be addressed to S.S.

Reprints and permissions information is available at www.nature.com/reprints.

Publisher's note Springer Nature remains neutral with regard to jurisdictional claims in published maps and institutional affiliations.

(c) (i) Open Access This article is licensed under a Creative Commons Attribution 4.0 International License, which permits use, sharing, adaptation, distribution and reproduction in any medium or format, as long as you give appropriate credit to the original author(s) and the source, provide a link to the Creative Commons license, and indicate if changes were made. The images or other third party material in this article are included in the article's Creative Commons license, unless indicated otherwise in a credit line to the material. If material is not included in the article's Creative Commons license and your intended use is not permitted by statutory regulation or exceeds the permitted use, you will need to obtain permission directly from the copyright holder. To view a copy of this license, visit http://creativecommons.org/licenses/by/4.0/.

(c) The Author(s) 2019 